\title{
ADVOKASI MEREK USAHA PADA WIRAUSAHA PEMULA DI KECAMATAN PRAMBON SIDOARJO
}

\author{
Andy Usmina Wijaya, Nurul Hudi, Argajendra Sentot \\ ${ }^{1}$ Fakultas Hukum Universitas 17 Agustus 1945 \\ ${ }^{2}$ Fakultas Hukum Universitas 17 Agustus 1945 \\ ${ }^{3}$ Fakultas Hukum Universitas 17 Agustus 1945 \\ andyusmina@uwp.ac.id
}

\begin{abstract}
Abstrak
Sampai saat ini sebagian besar wirausaha pemula yang akan melakukan kegiatan usaha tidak memiliki sebuah merek usaha yang tepat. Padahal merek merupakan roh dari dunia usaha agar berjalan dengan lancar terutama untuk barang dan atau jasa. Untuk itu salah satu hal yang harus dilakukan pertama kali oleh wirausahawan pemula saat akan memulai usahanya adalah merancang merek yang sesuai dan menggambarkan jiwa usahanya. Merancang merek usaha dengan mengkombinasikan ciri khas terkuat dari usaha dan menjadikannya sebagai daya tarik bagi target konsumen merupakan nilai tambah yang tak ternilai harganya. Oleh karena itu perlu adanya pendampingan hukum bagi para calon wirausaha pemula dalam memulai usahanya.

Tujuan dari kegiatan ini agar para wirausaha pemula di Kecamatan Prambon Sidoarjo memiliki suatu merek yang dapat mengenalkan usaha yang dibangunnya kepada konsumen. Advokasi merek pada wirausaha pemula ini dilaksanakan dengan melakukan sosialisasi kepada wirausaha pemula, mengidentifikasi permasalahan usaha yang ada, mendampingi wirausaha pemula dalam merancang merek usaha. Hasil pada kegiatan advokasi merek usaha ini adalah adanya 10 (sepuluh) merek usaha pada kegiatan usaha oleh wirausaha pemula.
\end{abstract}

Kata Kunci : Advokasi Hukum, Merek Usaha, Wirausaha Pemula

\section{PENDAHULUAN}

Mensejahterakan warganegara merupakan salah satu tugas dan kewajiban dari pemerintah seperti tertuang dalam Pembukaan Undang-Undang Dasar 1945 dengan cara meningkatkan pertumbuhan ekonomi masyarakat melalui sektor Usaha Mikro Kecil dan Menengah (selanjutnya disebut UMKM). Sejak Indonesia mengalami krisis moneter di tahun 1997 sektor UMKM mempu memberikan kontribusi untuk mendorong pertumbuhan ekonomi, bahkan bisa dikatakan bahwa UMKM dipandang sebagai penyelamat dalam pemulihan ekonomi nasional. Peranan penting UMKM lainnya adalah sebagai alternatif penyerapan lapangan kerja baru, penyedia barang yang murah untuk rakyat serta mencetak wirausaha lainnya.

Secara khusus UMKM memiliki peran yang penting pada bidang ekonomi maupun sosial terhadap negara berkembang seperti Indonesia. Hal tersebut nampak oleh karakteristik UMKM yakni, pertama, tersebar secara luas di berbagai daerah serta berperan dalam ekonomi daerah. Kedua, memiliki kemampuan dalam mempekerjakan tenaga kerja daerah sehingga dapat menunjang perkonomian lokal. Ketiga, memiliki kemampuan untuk menyediakan pengembangan keahlian bisnis dan wirausaha. Dengan karakteristik tersebut maka membuat UMKM tetap bertahan hidup walaupun kondisi usaha tidak menentu dan kompetisi usaha juga semakin ketat.

Ekonomi, Sosial, dan Budaya

1113 
Meskipun saat ini UMKM mndominasi kegiatan-kegiatan perekonomian masyarakat, UMKM ternyata masih meninggalkan masalah yang dapat menghambat pertumbuhannya. Beberapa permasalahan tersebut terkait dengan masalah kurangnya permodalan, masalah mengenai teknologi, manajemen, baik sumber daya manusia, pengadaan barang dan jasa, distribusi dan pemasaran (promosi).

Pemerintah Daerah Kabupaten Sidoarjo (selanjutnya disebut Pemda Sidoarjo) masih melihat UMKM merupakan prioritas pengembangan pemberdayaan masyarakat. Oleh sebab itu kebijakan serta program-program yang bertujuan melindungi dan mengembangkan UMKM telah dirumuskan dan diimplementasikan. Salah kebijakan program pengembangan pemberdayaan masyarakat adalah menciptakan wirausaha baru di kabupaten Sidoarjo.

Seiring dengan perkembangan teknologi menciptakan usaha baru merupakan salah satu hal yang ingin dilakukan oleh masyarakat saat ini. Akan tetapi memulai usaha yang baru sangat rumit. Beberapa kesalahan yang dilakukan oleh wirausaha pemula dalam memulai usahanya diantaranya adalah pertama, mereka tidak memiliki alasan yang tepat mengapa melakukan usaha. Padahal jika tidak memiliki jawaban untuk itu, maka wirausaha pemula akan terhalang untuk maju dan gampang menyerah. Kedua, dalam mengelola usaha dilakukan tanpa ada strategi yang jelas. Ketiga, berpikir kalau konsumen akan datang membeli produk usaha kita dengan sendirinya. Pemikiran tersebut jelas sangat salah, karena sebagai wirausaha yang pemula, untuk sukses mereka harus melakukan promosi secara besar-besaran agar konsumen.

Berkaitan dengan pemasaran (promosi) seringkali wirausaha baru melupakan unsur yang terpenting dalam pemasaran atau promosi produk barang yaitu merek. Padahal salah satu cara untuk melakukan promosi agar produk usaha dikenal oleh konsumen adalah dengan membangun merek usahanya. Mereka cenderung untuk tidak memiliki motivasi dalam membangun merek produk usaha miliknya.

Berdasarkan latar belakang tersebut maka kurang pahamnya wirausaha pemula dalam membangun merek usaha mereka, seringkali mempersulit pengembangan usaha yang dijalankan. Padahal, merek merupakan hal yang penting untuk pemasaran produk usaha. Oleh karena itu berdasarkan latar belakang tersebut maka permasalahan yang dapat diambil adalah arti pentingnya merek usaha bagi wirausaha pemula

\section{METODE}

Pendekatan pemberdayaan mengacu pada ekologi perkembangan (ecology of human development) dan lingkungannya yang menyatakan bahwa intervensi sosial harus dapat menyentuh seluruh level relasi antar-individu dan lingkungannya. Berdasarkan relevansi tersebut di atas, advokasi hukum merek usaha pada wirausaha pemula di kecamatan Prambon Sidoarjo dimulai dengan kegiatan:

1. Pemetaan wirausaha pemula di kecamatan Prambon Sidoarjo.

2. Peningkatan Pengetahuan dan Kesadaran Masyarakat masyarakat akan pentingnya penggunaan merek usaha untuk kegiatan usaha mereka.

3. Pendampingan hukum (advokasi hukum) merek usaha bagi wirausaha pemula di kecamatan Prambon Sidoarjo.

Secara keseluruhan, ringkasan pelaksaan advokasi merek usaha bagi para wirausaha pemula di kecamatan Prambon Sidoarjo dilakukan sebagai berikut :

1. Persiapan dan Pemetaan meliputi

a. Menyusun rencana program prioritas yang akan diselesaikan melalui advokasi merek usaha pada wirausaha pemula ini sesuai dengan potensi dan permasalahan yang ada;

b. Melaksanakan pemetaan kepada para wirausaha pemula yang belum memiliki merek usaha pada kegiatan usaha mereka di kecamatan Prambon Sidoarjo;

c. Menentukan wirausaha pemula yang belum memiliki merek usaha pada kegiatan usaha mereka sebanyak 20 wirausaha pemula;

d. Menyusun program-program pelaksaan kegiatan pengabdian berupa advokasi merek usaha;

2. Pelaksanaan Program Kegiatan meliputi:

Ekonomi, Sosial, dan Budaya

1114 
a. Melaksanakan observasi dan wawancara dengan wirausaha pemula;

b. Melakukan Pelatihan dan Penyuluhan tentang arti penting dari penggunaan merek usaha pada kegiatan usaha wirausaha pemula.

c. Melaksanakan pendampingan hukum (advokasi hukum) merek usaha bagi wirausaha pemula yang belum memiliki merek usaha.

\section{HASIL DAN PEMBAHASAN}

\section{Wirausaha Pemula Kecamatan Prambon}

Berdasarkan data yang diperoleh dari Badan Statistik Kabupaten Sidoarjo, Kecamatan Prambon merupakan salah satu kecamatan yang terletak di sebalah barat ibukota Kabupaten Sidoarjo. Seperti wilayah kecamatan lainnya di sebelah barat kabupaten Sidoarjo, Kecamatan Prambon merupakan kecamatan yang memiliki banyak lahan pertanian dibandingkan kecamatan lainnya yang ada di Kabupaten Sidoarjo. Keadaan ini menyebabkan tidak banyak industri yang berdiri di lahan kecamatan Prambon seperti kecamatan lainnya. Lahan pertanian terutama sawah mendominasi areal lahan di kecamatan Prambon sebesar 2124,40 ha.

Jumlah penduduk tetap yang mendiami kecamatan Prambon sebanyak 66,025 jiwa yang terdiri dari laki laki dan perempuan. Desa di wilayah kecamatan Prambon sejumlah 20 desa, 70 dusun, 74 Rukun Warga (RW), 337 Rukun Tetangga (RT).

Karena jumlah lahan pertanian mendominasi wilayah kecamatan Prambon maka salah satu keunggulan yang tampak di Kecamatan Prambon adalah hasil pertanian seperti padi dan sayur mayur. Hasil pertanian dari kecamatan Prambon memenuhi kebutuhan sayur mayur di kabupaten Sidoarjo.

Industrialisasi menempati posisi sentral dalam ekonomi masyarakat modern seperti kecamatan Prambon. Industrialisasi merupakan motor penggerak yang memberikan dasar bagi peningkatan kemakmuran oleh kecamatan Prambon dan mobilitas perseorangan yang belum pernah terjadi sebelumnya pada sebagian besar penduduk di dunia terutama di negara-negara maju. Sampai tingkat tertentu industri pasti mencerminkan karakter komunitas di mana industri itu bertempat : sarana transportasinya, lokasinya di tepi sungai atau jalan kereta api atau danau, sikapnya terhadap kerja, terhadap manajemen, terhadap pekerja. Begitu juga dengan hadirnya industri di pedesaan, kemunculannya memberikan perubahan besar terhadap kehidupan masyarakat di pedesaan. Mengingat masyarakat kecamatan Prambon Sidoarjo masih banyak untuk dibuat lahan pertanian akan tetapi masyarakat kecamatan Prambon Sidoarjo masih banyak yang memilih untuk bekerja di pabrik.

Industri diharapkan dapat menjadi motor penggerak perekonomian masyarakat di kecamatan Prambon, terutama masyarakat yang berada di sekitar lingkungan industri. Undang-undang Nomor 5 tahun 1984 menyatakan dalam pasal 3 bahwa salah satu tujuan pembangunan industri adalah untuk meningkatkan kemakmuran dan kesejahteraan rakyat secara adil dan merata dengan memanfaatkan sumber daya alam, dan atau hasil budidaya serta dengan memperhatikan keseimbangan dan kelestarian lingkungan hidup.

Jumlah wirausaha pemula di kecamatan Prambon Sidoarjo yang memulai usaha kurang dari 5 tahun tercatat sekitar 732 orang. Sedangkan kegiatan usaha yang dilakukan oleh wirausaha pemula tersebut bermacam macam, baik produk usaha berupa barang maupun jasa seperti, jual makanan kecil/camilan, pulsa, toko kelontong, warung kopi, dan lainnya.

\section{Keengganan Wirausaha Pemula Membangun Merek}

Beberapa wirausaha pemula di Kecamatan Prambon Kabupaten Sidoarjo yang telah memulai usahanya belum memiliki merek usaha. Hal tersebut dikarenakan mereka tidak mengetahui dan memahami mengenai pentingnya merek bagi usahanya. Mereka ragu dan untuk membangun merek usahanya dikarenakan beberapa mitos yang berkembang dalam masyarakat tentang merek usaha. Akibat yang terjadi adalah wirausaha pemula tersebut menjadi takut untuk membangun merek usahanya sendiri. Beberapa alasan yang menjadikan wirausaha pemula takut dalam membangun merek usahanya adalah

1. Biaya merek mahal

Mitos yang beredar di masyarakat bahwa untuk membuat merek membutuhkan biaya yang

$$
\text { Ekonomi, Sosial, dan Budaya }
$$


tidak sedikit merupakan salah satu alasan mengapa wirausaha pemula enggan untuk membangun merek usaha mereka. Terlebih lagi sebagian besar dari mereka masih memiliki keterbatasan modal usaha. Dengan alasan keterbatasan modal usaha inilah yang mengakibatkan mereka berusaha meminimalkan pengeluaran usahanya. Mereka berusaha mengoptimalkan modal usaha yang terbatas untuk menambah atau meningkatkan voleme produk usahanya daripada membangun merek usahanya.

Lebih lanjut dalam pandangan wirausaha pemula, membangun merek usaha lebih banyak menggunakan dana seperti untuk kebutuhan membuat iklan besar-besaran. Oleh sebab itu mereka tidak berminat untuk membangun merek untuk usahanya.

2. Membangun merek itu sulit

Wirausaha pemula di kecamatan Prambon Sidoarjo masih meyakini mitos yang berkembang di masyarakat bahwa sangat sulit untuk memnbangun merek usaha. Namun sebenarnya membangun sebuah merek usaha itu tidaklah serumit yang dibayangkan oleh mereka. Perlu dipahami bahwa inti dari kegiatan membangun serta mengembangkan merek usaha adalah bagaimana mereka dapat menciptakan kesan yang tepat yang ada di benak konsumen. Cara yang tepat untuk membangun merek usaha diantaranya adalah dengan membangun nilai produk, diferensiasi produk, dan mengkomunikasikan nilai-nilai tersebut kepada konsumen.

3. Wirausaha Pemula tidak perlu membangun merek,

Mitos dari masyarakat mengenai tidak perlu membangun merek adalah salah. Hal ini dikarenakan semua usaha, baik itu usaha besar, menengah ataupun usaha kecil dan mikro pasti membutuhkan merek usaha. Hal tersebut dilakukan karena dari merek usaha tersebut memberikan manfaat untuk usahanya dan bida menjadi modal bagi wirausaha pemula dalam menggunakan bisnis lebih lanjut.

\section{Arti Pentingnya Merek Bagi Wirausaha Pemula}

Apabila diperhatikan seorang konsumen membeli sebuah produk dipengaruhi oleh beberapa faktor, mulai dari faktor harga maupun non harga. Salah satu yang merupakan faktor non harga yang menjadi pertimbangan konsumen adalah kualitas dan merek usaha dari produk usaha tersebut. Secara umum, konsumen akan memilih merek usaha yang terkenal serta bekualitas dan populer dalam masyarakat.

Fungsi utama dari sebuah merek usaha adalah agar konsumen dapat mencirikan suatu produk baik barang maupun jasa yang dimiliki wirausaha pemula sehingga konsumen dapat membedakan dengan produk usaha lainnya yang serupa atau yang mirip. Konsumen yang merasa puas oleh suatu produk tertentu, pasti akan membeli atau memakai kembali produk usaha tersebut dimasa yang datang. Konsumen terkadang juga sering memakai faktor emosional pada merek tertentu berdasarkan rentetan kualitas yang diinginkan yang terwujud dalam produk usaha tersebut.

Untuk itu salah satu cara dalam meningkatkan sebuah usaha adalah dengan membangun merek usaha. Merek akan membuat produk usaha kita akan mendapatkan identitas yang membedakan produk dengan produk lainnya yang sejenis.

1. Membuat produk usaha kita dikenal Merek usaha pasti menempel pada produk usaha kita, sehingga dapat diibaratkan wajah dari suatu usaha. Dengan demikian pasti akan menempel pula pada ingatan dari konsumen yang membeli atau menjumpai produk kita. Perlu diingat bahwa dalam persaingan usaha jumlah pesaing akan semakin banyak, sehingga keragaman merek juga semakin banyak pula. Hal tersebut yang menjadikan produk usaha kita harus memiliki merek usaha agar dikenal oleh konsumen.

2. Konsumen akan percaya pada produk usaha kita

Ada kecenderungan bahwa konsumen pasti lebih memilih suatu barang yang sudah jelas merek usahanya dibandingkan produk usaha yang belum memiliki merek. Konsumen tidak mau mengambil risiko untuk membeli barang-barang yang tidak jelas asal usulnya. Sehingga merek usaha dapat membantu konsumen untuk mempercayai suatu produk usaha. Namun harus diingat oleh wirausaha pemula bahwa semuanya kembali pada kualitas dari produk usahanya itu sendiri. Apabila produk usahanya tidak baik, maka secara otomatis citra dari merek usaha tersebut akan jelek.

$$
\text { Ekonomi, Sosial, dan Budaya }
$$


3. Merek membantu dalam promosi produk usaha

Dengan memiliki merek usaha, maka akan memudahkan wirausaha pemula dalam mengenalkan produk usaha kepada konsumen. Jika produk usaha tersebut memiliki merek yang perlu dilakukan wirausaha pemula hanya terus meningkatkan kualitas produk usahanya dan menjaga citra merek usahanya. Merek usaha juga dapat menjadi nilai tambah bagi wirausaha pemula untuk berinvestasi dalam memelihara dan meningkatkan kualitas produk usaha yang mereka miliki guna menjamin bahwa produk usaha mereke memiliki reputasi yang baik. Dengan memilih merek yang tepat merupakan aset usaha yang berharga.

\section{Advokasi Merek Kepada Wirausaha Pemula}

Merek menurut ketentuan Undang-Undang Nomor 20 Tahun 2016 Tentang Merek pasal 1 ayat 1 adalah tanda yang dapat ditampilkan secara grafis berupa gambar, logo, nama, kata, huruf, angka, susunan warna, dalam bentuk 2 (dua) dimensi dan/ atau 3 \{tiga) dimensi, suara, hologram, atau kombinasi dari 2 (dua) atau lebih unsur tersebut untuk membedakan barang dan atau jasa yang diproduksi oleh orang atau badan hukum dalam kegiatan perdagangan barang darr/ atau jasa. Hampir semua bentuk dapat dijadikan merek usaha, namun ada beberapa hal yang tidak dapat dijadikan merek usaha yaitu pada pasal 20 yang menyebutkan merek tidak dapat didaftar jika:

a. bertentangan dengan ideologi negara, peraturan perundang-undangan, moralitas, agama, kesusilaan, atau ketertiban umum;

b. sarna dengan, berkaitan dengan, atau hanya menyebut barang dan atau jasa yang dimohonkan pendaftarannya;

c. memuat unsur yang dapat menyesatkan masyarakat tentang asal, kualitas, jenis, ukuran, macam, tujuan penggunaan barang danj atau jasa yang dimohonkan pendaftarannya atau merupakan nama varietas tanaman yang dilindungi untuk barang danjatau jasa yang sejenis;

d. memuat keterangan yang tidak sesuai dengan kualitas, manfaat, atau khasiat dari barang danj atau jasa yang diproduksi;

e. tidak merniliki daya pembeda; dan / atau f. merupakan nama umum dan./atau lambang milik umum.

Selanjutnya pasal 21 menerangkan bahwa perrnohonan pendaftaran merek ditolak jika Merek tersebut mernpunyai persamaan pada pokoknya atau keseluruhannya dengan:

a. Merek terdaftar milik pihak lain atau dimohonkan lebih dahulu oleh pihak lain untuk barang dan atau jasa sejenis;

b. Merek terkenal milik pihak lain untuk barang dari/atau jasa sejenis;

c. Merek terkenal milik pihak lain untuk barang dan/atau jasa tidak sejenis yang memenuhi persyaratan tertentu; atau

d. Indikasi Geografis terdaftar.

e. rnerupakan atau menyerupai nama atau singkatan nama orang terkenal, foto, atau nama badan hukum yang dimiliki orang lain, kecuali atas persetujuan tertulis dari yang berhak;

f. merupakan tiruan atau menyerupai nama atau singkatan nama, bendera, lambang atau simbol atau emblem suatu negara, atau lembaga nasional maupun internasional, kecuali atas persetujuan tertulis dari pihak yang berwenang; atau

g. merupakan tiruan atau rnenyerupai tanda atau cap atau stempel rcsmi yang digunakan oleh negara atau lembaga Pemerintah, kecuali atas persetujuan tertulis dari pihak yang berwenang.

h. beriktikad tidak baik.

Wirausaha pemula perlu memperhatikan beberapa hal dalam membuat merek usaha mereka. Pertama, terlebih dahulu memeriksa merek usaha tersebut telah memenuhi persyaratan hukum merek. Kedua, wirausaha pemula perlu melakukan penelusuran merek untuk meyakinkan bahwaw merek usaha yang digunakan tersebut tidak memiliki kemiripan dengen merek usaha lainnya. Ketiga, merek usaha yang digunakan dapat dibaca, ditulis, dieja dan diingat dengan mudah. Keempat, wirausaha pemula perlu juga memastikan bahwa merek usaha yang digunakan tidak memiliki konotasi yang tidak baik atau negatif dalam bahasa di negara manapun.

Tata cara pembuatan merek harus dimengerti dan dipahami oleh wirausaha pemula agar Ekonomi, Sosial, dan Budaya

1117 
dikemudian hari tidak menjadi permasalahn yang berimbas pada sanksi hukum yang meliputi sanksi hukum administrasi, sanksi hukum perdata dan sanksi hukum pidana.

Beberapa kegiatan yang dilakukan untuk membantu wirausaha pemula dalam membuat serta membangun merek usaha mereka. Diantaranya dengan melakukan workshop pembuatan merek usaha. Pada kegiatan tersebut wirausaha pemula di kecamatan Prambon Sidoarjo yang belum mempunyai merek usaha dibimbing dalam pembuatan merek usaha mereka. Mereke diberikan materi mengenai cara penyusunan merek usaha, persyaratan yang harus dipenuhi dalam membuat merek usaha, perlindungan hukum merek usaha sampai dengan penerapan sanksi bagi mereka yang melanggar merek usaha. Setelah pemberian materi penyusunan merek usaha, wirausaha pemula dibimbing untuk praktek membuat merek yang sesuai dengan ketentuan hukum merek usaha yang berlaku.

Selain itu dengan memanfaatkan teknologi informasi wirausaha pemula dapat melakukan konsultasi sehingga pembuatan merek dilakukan dengan benar. Kehadiran teknologi tertutama teknologi informasi sangat membantu dan mempermudah segala kegiatan mansusia ini. Peranan tekonologi informasi yang sedemikian besar harus dimanfaaarkan secara maksimal terutama pada kegiatan membangun merek bagi wirausaha pemula di Kecamatan Prambon Sidoarjo. Pada jaman internet ini mempengaruhi kehidupan perekonomian, pengetahuan, sosial dan budaya dengan cara sebagai media dalam menggabungkan segala aktivitas manusia. Sehingga internet membantu penyebaran informasi dan komunikasi semakin cepat melalui multimedia yang digunakan seperti aplikasi email, whatsapp maupun facebook. Wirausaha pemula di kecamatan Prambon Sidoarjo melakukan konsultasi dan advokasi merek usaha mereka melalui aplikasi media sosial.

Hasil dari kegiatan advokasi merek usaha pada wirausaha pemula di kecamatan Prambon Sidoarjo adalah terbangunnya merek usaha sebanyak 10 (sepuluh) buah merek. Kegiatan usaha yang memiliki merek tersebut meliputi usaha makanan ringan pengolahan ikan, usaha warung makanan, usaha warung kopi, usaha pengisian pulsa serta usaha kerajinan tangan.

\section{KESIMPULAN}

1. Kesimpulan

Sebagian besar wirausaha pemula di kecamatan Prambon Sidoarjo belum memiliki merek usaha dalam kegiatan usaha mereka. Hal ini disebabkan karena kurang pahamnya wirausaha pemula mengenai arti penting merek usaha bagi kegiatan usaha mereka. Pada kegiatan pengabdian ini wirausaha pemula yang telah menggunakan merek usaha pada kegiatan usaha mereka sebanyak 10 wirausaha pemula.

2. Saran

Sosialisasi mengenai arti penting merek usaha kepada wirausaha pemula secara kontinyu di kecamatan Prambon Sidoarjo. Perlu adanya pendampingan hukum (advokasi) mengenai merek usaha secara berkelanjutan kepada para wirausaha pemula agar produk usahanya memiliki merek usaha untuk dikenal oleh konsumen. Diharapkan penggunaan merek usaha bagi wirausaha pemula di kecamatan Prambon Sidoarjo semakin banyak.

\section{UCAPAN TERIMAKASIH}

Ucapan terima kasih disampaikan kepada Program Doktor Ilmu Hukum Universitas 17 Agustus 1945 Surabaya yang telah memberikan kesempatan kepada penulis untuk melakukan pengabdian kepada masyarakat di Kecamatan Prambon Sidoarjo.

\section{REFERENSI}

Abdulkadir Muhammad, Kajian Hukum Ekonomi dan Hak Kekayaan Intelektual, Citra Aditya Bhakti, Bandung, 2011.

Budi Agus Riswandi \& M. Syamsudin, Hak Kekayaan Intelektual dan Budaya Hukum, Raja Grafindo Persada, Jakarta, 2004.

Friedmann W, The State and The Rule of Law in A Mixed Economy, Steven and Sons, London, 1971 
Insan Budi Maulana, Sukses Bisnis Melalui Merek, Paten dan Hak Cipta, Citra Aditya Bhakti, Bandung, 1997

Kansil, C.S.T, Hak Milik Intelektual, Paten, Merek Perusahaan, Merek Perniagaan, Hak Cipta, Bumi Aksara, Jakarta, 1990

Mochtar Kusumaatmadja, Hukum Masyarakat dan Pembangunan Hukum Nasional, Bina Cipta, 1976.

Saidin, Aspek Hukum Hak Kekayaan Intelektual, TP. Raja Grafindo Persada, Jakarta, 2003
Sonny Keraf, Etika Bisnis-Membangun Citra Bisnis sebagai Profesi Luhur, Kansius, Yogyakarta, 1993.

Sumantoro, Hukum Ekonomi, UI Press, Jakarta, 1986

Tom Gunadi, Ekonomi dan Sistem Ekonomi Menurut Pancasila dan UUD 1945, Angkasa, Bandung, 1995. 